\title{
A FRICTION OF CULTURAL VALUES AND CHARACTERISTICS OF IMPERIAL MOSQUE IN TERNATE
}

Muhammad Tayeb

Sherly Asriany

Ridwan

\author{
Universitas Khairun Ternate \\ Indonesia \\ m.tayeb_m@yahoo.com
}

Universitas Khairun Ternate

Indonesia

Universitas Khairun Ternate

Indonesia

Received: November $27^{\text {th }} 2014$; Accepted: February $24^{\text {th }} 2015$; Available Online: June $15^{\text {th }} 2015$

\begin{abstract}
Indonesia has many religious culture that should be preserved one of which is the imperial mosque. Most of the imperial mosque has its own characteristics in carrying out activities both religious and cultural. Sultanate of Ternate is the largest sultanates in eastern Indonesia which would give other peculiarities that need to be raised as a typical Indonesian culture. The purpose of this study is to identify the type of tradition in doing at the mosque sultanate by people of Ternate and changes in cultural values of the people of Ternate in the imperial mosque. In this study found the phenomenon characteristic changes in cultural values by linking changes in the physical aspect and non-physical. To determine the effect of these factors, the method used is the method of observation of physical traces. This method is expected to be able to explain the effect of the change occurred. Based on the results of the study indicate compliance is still customary rules of religious traditions in the imperial mosque although some traditions that formerly taboo has been done, the progress of the times, increase knowledge, and make the implementation of the reform and renewal of cultural values carried by the community for various reasons theTernate.
\end{abstract}

Keywords: cultural; mosque; Ternate

\section{Introduction}

Indonesia has many religious culture that should be preserved one of which is the imperial mosque. Most of the imperial mosque has its own characteristics in carrying out activities both religious and cultural. Sultanate of Ternate is the largest sultanates in eastern Indonesia which would give other peculiarities that need to be raised as a typical Indonesian culture.

The people in Ternate is known as a religious community. Daily behavior of society is heavily influenced by nature spiritual mind. In everyday life, they have a special relationship with nature. Religion and culture as a historical reality can affect each other because both are values and symbols. Religion is a symbol that represents the value of obedience to God.

Table 1. The Differences of Mosques in Indonesia

\begin{tabular}{|c|c|c|}
\hline Traditional Mosque & Tomb Mosque & Modern Mosque \\
\hline $\begin{array}{l}\text { The roof is called Meru } \\
\text { intercropping derived from }\end{array}$ & $\begin{array}{c}\text { There is a Mihrab (the place of imam leading } \\
\text { the prayers) }\end{array}$ & \multirow{2}{*}{$\begin{array}{l}\text { The roof of the mosque is } \\
\text { influenced by Persian and } \\
\text { Indian culture that shaped } \\
\text { dome. The form of a half } \\
\text { dome- shaped Buddhist } \\
\text { stupa itself; there also } \\
\text { comes a tomb }\end{array}$} \\
\hline $\begin{array}{c}\text { palm fiber / thatch with an } \\
\text { odd number between } 2,3,5 \\
\text { and the top level is called } \\
\text { pyramid }\end{array}$ & $\begin{array}{l}\text { Examples: Demak mosque, is also called the } \\
\text { Holy Mosque, because usually there is a tomb } \\
\text { of a king and his relatives behind the } \\
\text { trustees. Ampel mosque, } \\
\text { Demak, Kudus, use the } \\
\text { tower for the muezzin }\end{array}$ & \\
\hline
\end{tabular}

Religion is a symbol that represents the value of obedience to God. Culture also contains the values and symbols so that people can live in it. Substance (contents) is a form of abstract primary 
culture of all kinds of new ideas and emerging human beings in society and giving life to the community itself, in both form and system of knowledge, values, way of life, beliefs, perceptions, and cultural ethos [1].

A good culture values have always be desired, aspired and considered important by all members of society, because culture has a value of truth, beauty, goodness, and religious. These values can be shifted in terms of people's behavior and traditions of the community in the event of an acculturation traditions and cultural activities is a form of traditional Indonesian society that is still widely carried by the supporting community.

Its role is to always remind people associated with the existence and relationship with the community. Until now the existence of a religious ceremony is still recognized as well-executed, although the forms and have different ways.

System of religion in society, especially in the religious system centered on the people of Ternate Empire Mosque. Tradition or religious rituals are held in the mosque. In contrast with mosques in general, the Imperial Mosque of Ternate also called Sigi Lamo. This famous mosque is unique because it has the customary rules that has consequences for social change. The religious system also experienced a shift. The shift itself is in the public understanding of the value or meaning of the tradition, because that has a different understanding of tradition. New experiences, new technologies make the human way of life adjustments and new habits.

Changes in cultural values of the people of Ternate in the imperial mosque is a phenomenon that occurred about 15 years. Various elements influence the language shift among the influx of other cultures or other ethnic areas and the availability of facilities and infrastructure are considered more convenient and time saving implementation.

The purpose of this study is to identify the type of tradition in doing at the mosque sultanate by people of Ternate and changes in cultural values of the people of Ternate in the imperial mosque. Research on the shift value of acculturation and characteristic building of the mosque architecture in North Maluku, has never been done. As similar studies that have been done by Faqih (1991) [2], the Typology of Mosque Architecture Without Architects in Java, and our previous research studies on Geometry of Aesthetics Architecture Mosque In Ternate, but this study did not discuss in detail and more about the value of culturation cultural and architectural characteristics mosque in Ternate.

\section{Humans and Culture}

Values of culture also contains symbols that humans can live in it. Substance (content) is a form of abstract primary culture of all kinds of new ideas and emerging human in society and give life to the community itself, in both form and system of knowledge, values, way of life, beliefs, perceptions, and cultural ethos [1].

The word culture comes from the word buddhayah as the plural of buddhi (Sanskerta) which means 'sense' [3]. The oldest definition can be seen from E.B. Tylor expressed in his book Primitive Culture (1871) [4]. According to Tylor, culture is the whole of human activity, including knowledge, belief, art, morals, law, customs, and other habits [4]. Edge definition proposed by Marvin Harris [5] that all aspects of human life in society, which is obtained by means of learning, including the mind and behavior.

According to Koentjaraningrat, there are three kinds of culture form: a) culture as a complex of ideas, ideas, values, norms, and regulations; b) culture as a complex behavior pattern of human activity in society; and c) the objects of human work [3]. There are also cultural grouping into: a) language; b) livelihood; c) organization; d) science; e) religious (ife; f) art; and g) technology.

\section{Relationships, Culture, Behavior, and Actors of Built Environment}

Human relationship with the environment proxies, is a tangle of interdependencies between each other (transcational interdependency). That is, humans affect the environment and vice versa, the environment affects humans.

According to Ismail Raji al-Faruqi, the main feature of which is classified into four categories based on the main characteristics shared by all Islamic art [6], is as follows; The units of content, architecture or structure of the interior space, landscaping (horticulture and Aquaculture), and the design of cities and villages.

\section{Planning Mosque}

To design a mosque, three prerequisites required, which means to be able to stimulate devotation in worship. The three prerequisite is, first: should always be clean, in the sense of easy to clean and easy to maintain. Second, is calm, which is creating the "atmosphere" that led to the birth of tranquility, and third, is "sacred but friendly". 
Mosques in Indonesia contains elements of the culture of the past that is also reminiscent to the style of some sacred buildings like temples. Temple of which is used to place the ashes of kings were regarded as a god-king. Similarly, the King / Sultan by people considered to be the sacred that has magical elements

In Indonesia, the mosque is divided into 3 types; traditional mosques, tombs mosques and modern mosques. They can be described to the Table 1.

\section{Method}

\section{Research Location and Time}

Ternate city is located under the foot of Mount Gamalama in North Maluku Province.

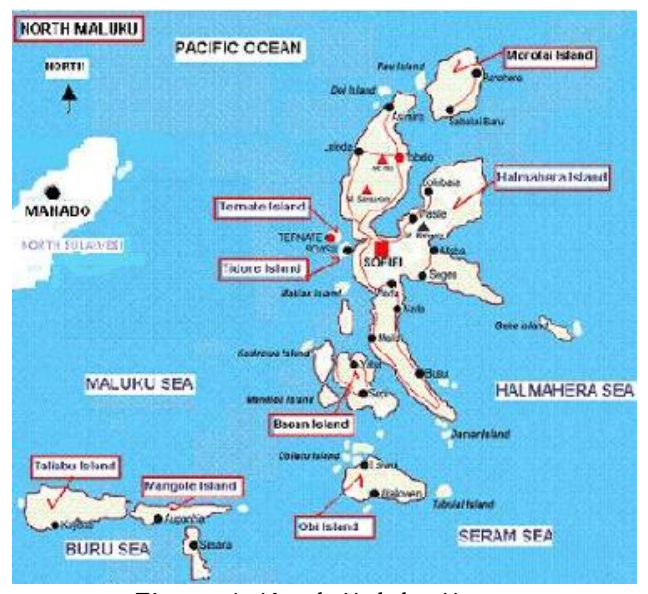

Figure 1. North Maluku Map

Source: Mediainfo.net, 2014

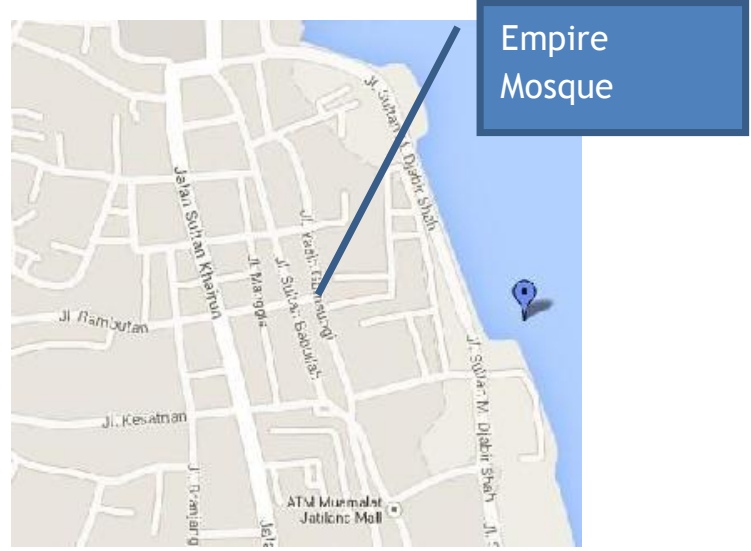

Figure 2. Empire Mosque Of Ternate Source: Mediainfo.net, 2014

Method or approach used in this study is the method of observation of physical traces. This method is expected to be able to explain the effect of the change occurred. Research activities will be carried out field surveys with the research stages and expected outcomes can be seen in the implementation of research procedures.

\section{Data Collection}

\section{a. Primary Data}

Field survey in order to get a picture directly at this time, in four locations of Sultanate Mosque and interviews with mosque or people who know in detail the history and culture as well as the activities carried out in the sultanate mosque

\section{b. Secondary Data}

Collecting data on the presence or removal of the initial location of the mosque is by tracking the location of the old maps and records of the secretary of the empire and the study of literature and documents that are in the government.

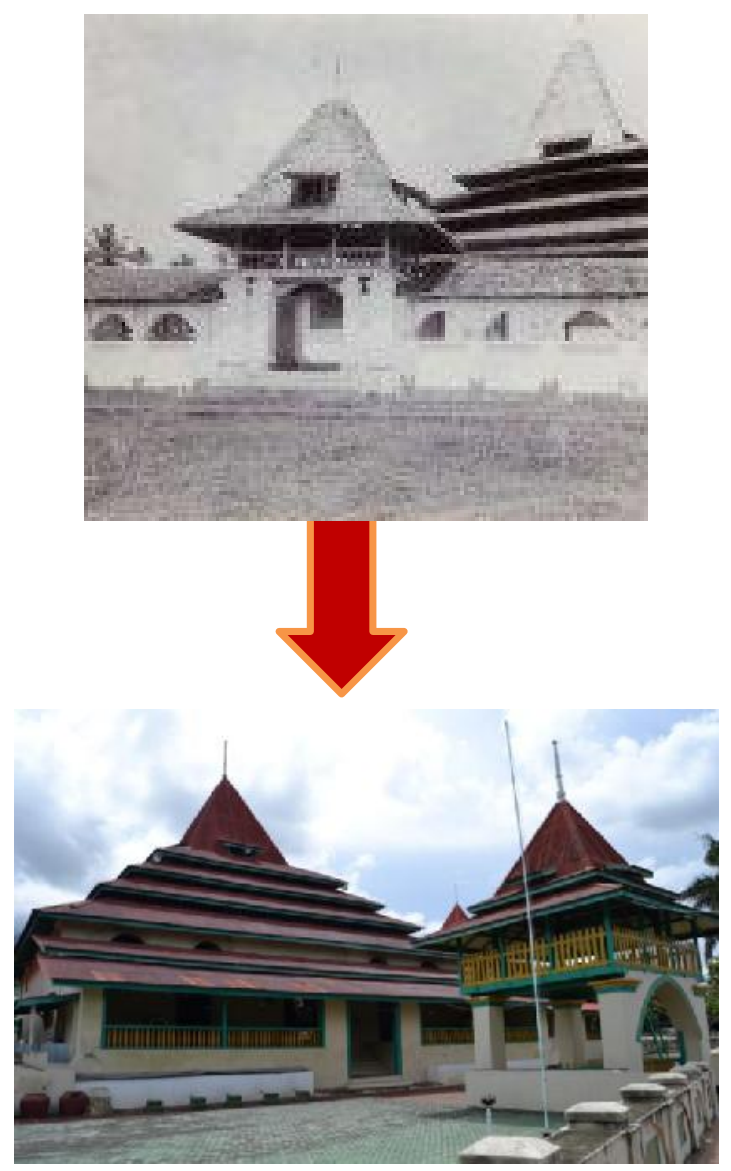

Figure 3. Empire Mosque Of Ternate Source: roeslyblog and researchers ,2014

\section{Result and Discussion}

Ternate society is a religious society. All activities are filled with a series of ceremonial rituals. Ternate Imperial Mosque is a mosque located in the area of Jalan Sultan Khairun, Village 
Soa Sio, District of North Ternate, Ternate. The mosque is a proof of the existence of the first Islamic Empire in eastern Nusantara. Empire Ternate started to embrace Islam since the 18th king, namely Kolano Marhum who reigned about 1465-1486 AD.

Substitute Kolano Marhum is his son, Zainal Abidin (1486-1500), which further solidify the Islamic Empire of Ternate as by changing the title Kolano a Sultan, declares Islam as the official religion of the empire, to impose Islamic law, as well as forming the royal institution in accordance with the Islamic law involving the clergy. As with other Islamic Empire in Nusantara, Ternate Empire Mosque was built not far from the palace of the Sultan of Ternate, but not be part of the palace complex. The distance between them is about 100 meters south- east of the Sultan's palace that was built in $1234 \mathrm{AD}$. The position of the mosque is of course related to the important role of the mosque in religious life in Empire Ternate.

The shift in the values intrinsic to the culture and everyday life in North Maluku society affect the development of the mosque, where these changes can be either physical or nonphysical changes. With the shift and the change in the issue that arises is; factors influencing these changes and physical and non-physical changes contained in the building of the mosque architecture.

Change or shift in culture that has long been run by the Sultanate of Ternate can be seen in the following discussion;

\section{Cultural Rituals \\ Kolano Uci Sabea}

Kolano Uci Sibea usually starts from the palace to the mosque to carry out Tarawih prayers. Around seven-thirty local time, the sultan will be guided by the royal troops to the mosque and accompanied by the strains of music instruments Totobuang (sort of gamelan) is played by a dozen small children dressed in traditional clothes in front of complete litters sultan. That said, this instrument is given by Maulana Malik Ibrahim (Sunan Gresik) when one of the Sultan of Ternate studied him. Before the Tarawih prayers performed, the muezzins which consists of four people, a call to prayer together. According to some people, is to remind people of Ternate about four Soa (first village) in the area of Ternate. Four is the Soa Soa Heku (Village Dufa-Dufa), Soa Cim (Village Makassar), Soa Break (Village Koloncucu), and Soa Mosque sultan himself.
After carrying out the Tarawih, the sultan will return to kedaton with crutches back as when his departure to the mosque. In kedaton sultan with the empress (Boki) will offer prayers in a special room, precisely on the ancestral shrine. After praying, the Sultan and consort will accept the people to meet, shake hands, even kissing the feet of sultan and the queen as a sign of loyalty. Of course, a direct meeting between the sultan and his subjects of interest to a whole community in Ternate and the surrounding islands.

In one year, the ritual Kolano Uci Sabea executed four times, including at night Qunut, Lailatul Qadr Night (both in the month of Ramadan), and the Eid al- Fitr and Eid al-Adha. Implementation Kolano Uci Sabea done by any hereditary Sultan of Ternate until now. According to the trust, under any circumstances Kolano (Sultan) must do Sabea (salat) at Sigi Lamo (Sultan Mosque).

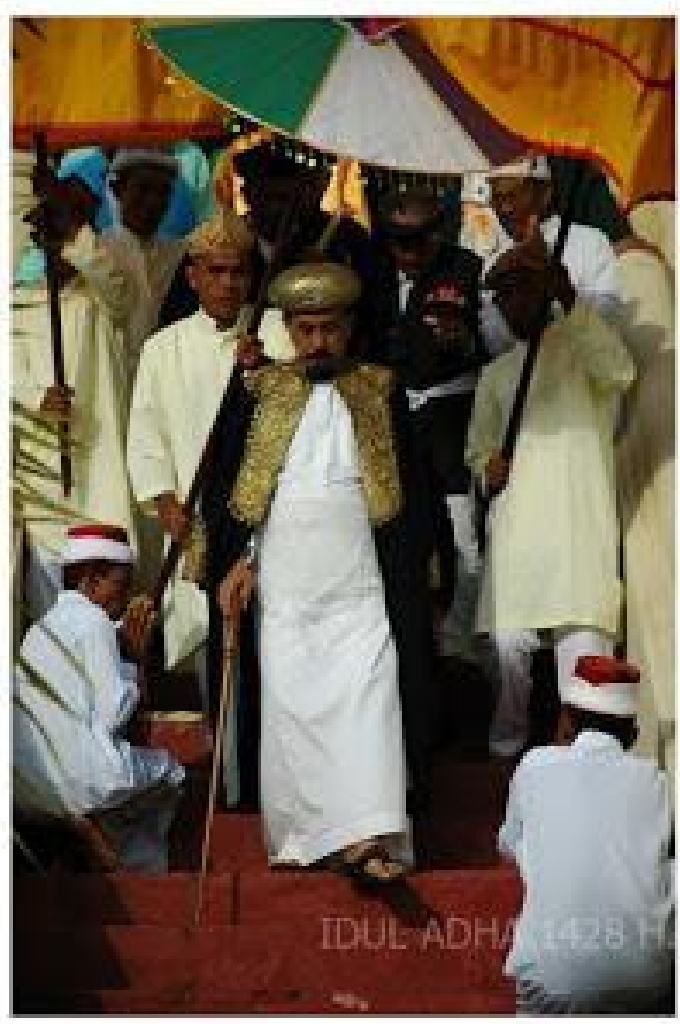

Figure 4. Kolano Uci Sibea

(Source: molied,acc. 2014)

In the implementation of the Eid al-Adha 1428 H, 2007 AD Sultan Shah II Mudaffar decision not on the stretcher again by the subjects in the indigenous peoples of Ternate. This decision was taken on the considerations and current conditions. 


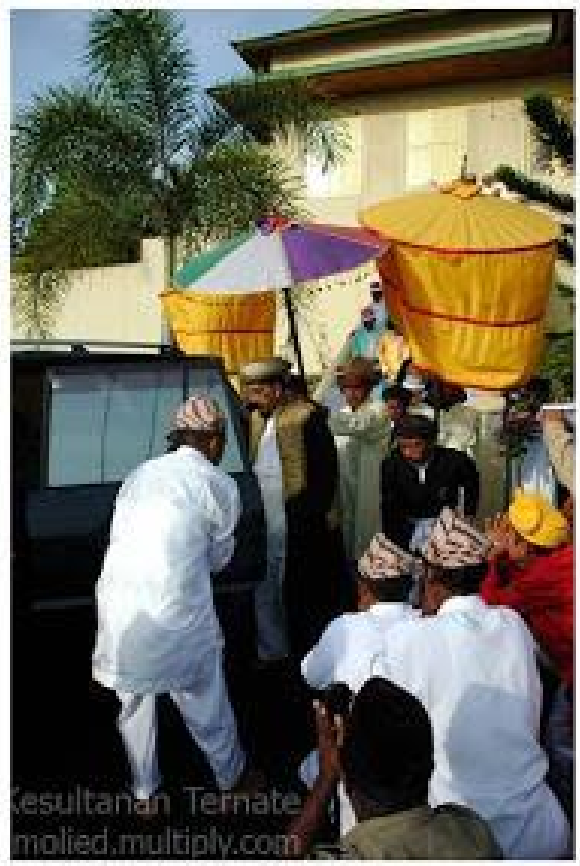

Figure 5. Cultural shift In Mosque Ternate Traditional (Source: molied,acc. 2014)

\section{Prayer and Procession}

Implementation of dressing procedures:

- These rules were said to have originated from the ancestors admonished (called Doro bololo, Proposition Tifa, and Proposition Moro) which is still adhered to by people of Ternate Prohibition of wearing a sarong or long pants to wear for the congregation, the Prohibition of the pilgrims to wear gloves or clothes like that are based on reason Sufism. According to their belief, the position of the feet when praying with a man wearing trousers showed the letter Alif Lam significant inverse two sentences creed. It is a symbol that the person has been admitted to the oneness of Allah and Muhammad as his messenger, so that body and soul are ready to implement praying. Therefore, any man who will carry out the worship must wear long pants

- The obligation to wear a head covering (cap), which allowed head cap is a black cap, white cap (hajj), towel kuraci (yellow cap), towel bubudo (white hat), towel batik (batik cap), lastar and the style of headgear priests Ternate, the preacher and the modem (red and white belt).

- The prohibition for women to worship in this mosque. Ban women from worship in the mosque is based on the reason for maintaining the sanctity of the mosque, the place of worship that is not inadvertently woman suddenly came in (menstruation).

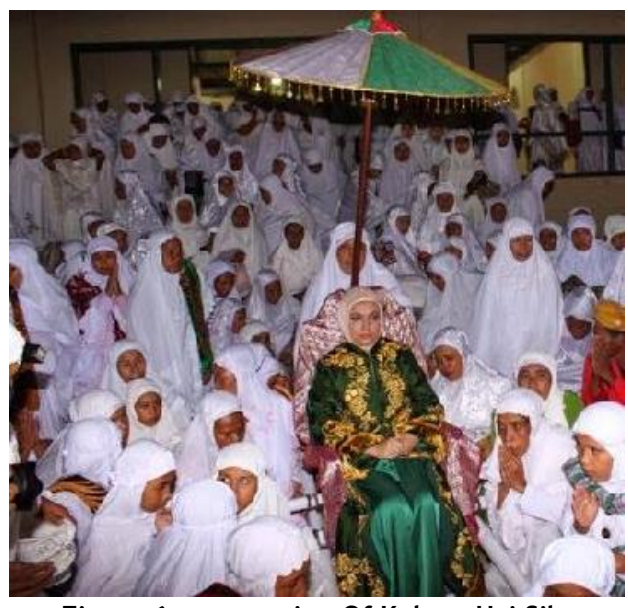

Figure 6. procession Of Kolano Uci Sibea Source: molied,acc. 2014

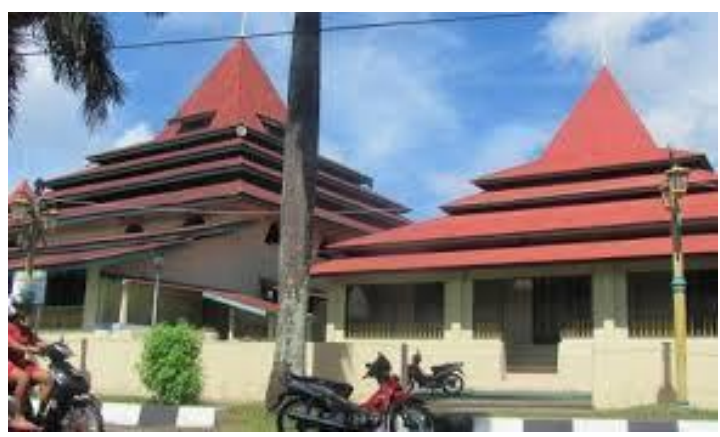

Figure 7. Mosque for women who are on the right side of the Sultanate of Ternate Mosque Source: Republika.co.id,2014

\section{Conclusion}

From the research that has been said above, it can be concluded that a tradition of cultural rituals is never separated from the rules that must be adhered to strictly by the people, especially indigenous peoples. Shifting the traditional values that occur look at various things in the shalat and some cultures today.

a. First mosque still use thatch as roof now has turned into a tin roof, because the difficulty in obtaining raw materials, especially in the area of Ternate, and the difficulty of finding people who want to make the material.

b. The ritual of Kolano Uci Sabea procession previously used a stretcher to the Sultan marched toward the imperial mosque has 
now been changed to driving a car. Sultan of Ternate age factors that influence changes in the procession Kolano customs Uci Sabea

c. Ablution a pond and water faucet that used to be in front now moved laterally, and the pool is not used anymore now

d. The prohibition of women praying in the mosque when the sultanate has awoken also a place of prayer for women who are right beside the imperial mosque

That is some shift we can conclude from this study, further in subsequent research studies leading to the mosque building Ternate sultanate form. In a culture that is full of tradition elements of the old belief now prefer the elements of Islam. The reason people change is the tradition:
a. Practically
b. Optimized efficiency
c. Limited facilities
d. The more conscious people would be the rules of religion

e. Operational cost savings. The positive impact of this phenomenon is the increase of public understanding of the teaching of Islam

\section{References}

[1] E. M. Setiadi, Ilmu Sosial dan Budaya Dasar. Jakarta: Kencana, 2008.

[2] M. Faqih, J. Prijotomo, and Murtijas, "Tipologi Arsitektur Masjid Tanpa Arsitek di Surabaya," Surabaya, 1991.

[3] Koentjaraningrat, Pengantar Antropologi. Jakarta: Aksara Baru, 1974.

[4] E. B. Tylor, Primitive Culture. 1871.

[5] M. Harris, Theories of Culture in Postmodern Times. New York: Altamira Press, 1999.

[6] I. R. Al-Faruqi, Seni Tauhid: Esensi dan Ekspresi Estetika Islam. Yogyakarta: Yayasan Bentang Budaya, 1999. 